\title{
NILE TILAPIA (Oreochromis niloticus) CULTIVATION IN WATER RICE FIELDS, 2- EFFECT OF ARTIFICIAL DIETS SUPPLEMENTED ON GROWTH PERFORMANCE
}

\author{
F.F. Khalil ${ }^{1}$ and M. E. A. Seden ${ }^{2}$ \\ 1- Department of Animal Production, Faculty of Agriculture, Mansoura University, \\ Egypt, 2- Center Laboratory of Fish Research, Abbassa Abo-Hamad Sharkia, Egypt
}

\section{SUMMARY}

The present study was carried out during 2002 (at $17^{\text {th }}$ July to $15^{\text {th }}$ October) on Nile tilapia (Oreochromis niloticus) in Sherbeen Center of land cultured by rice yield, Dakahlia Governorate. The results obtained could be summarized in the following: Effects of protein diet \% and protein intake had significantly $(P \leq 0.01)$ improved tilapia body weight and body weight gain at different experimental intervals, and increased with increasing the previous factors studied. Also, treatment diets (2-6) improved $(P \leq 0.01)$ body weight than control diet (T1). The $3^{\text {rd }}$ tested diet $(30 \% \mathrm{CP})$ and high level of protein intake recorded the best values of $R G R \%$ and $K$ factor than those calculated for another diets (tested or control). Thus, using the highest dietary protein $(30 \% \mathrm{CP})$ and level of protein intake $(0.09 \mathrm{~g} / 100 \mathrm{~g}$ fish body weight) improved significantly all the previously parameters measured than those lowers. This study indicate that the quantity of natural food was not enough to faster increasing Nile tilapia growth, therefore, artificial diets must be used in feeding fish, especially, the period of fish cultivation in water rice field is the shortest time (3 months).

Keywords: Nile tilapia, water rice fields, growth performance

\section{INTRODUCTION}

Bardach et al. (1972), Sivalingam (1975), Eid (1993) and Abdelhamid (2000) they reported that Oreochromis niloticus is a plankton feeder, an omnivorus and can feed on higher plants to the extent that it may be used in weed control. They also, stated that tilapia species feed on algae, other plants, detritus and other materials found in the pond bottom. Feeding rates for tilapia are affected by fish species and size, energy level in the diet, water quality, feeding frequency and the availability of natural foods (Bolarin and Haller, 1982, and Eid, 1993). Tilapia, like many other cultured of fish species, benefit from multiple feeding. Small sizes of fish should be fed more often than larger fish and the feeding frequency is decreased as the fish increase in size (Abdelhamid et al., 1997). The fish preferred the artificial diet, followed by phytoplankton diet, this confirms the phytoplanktivorous habit of this fish species its diet, and is filtered, non-visual perdition (Loares et al., 2001). Artificial diets as the sources of protein in fish culture. Dietary protein is always considered to be of primary importance in fish feeds, as the protein requirements of fish are higher than those of terrestrial animals and protein sources account for more 
half of total feed cost (El-Ebiary, 1994). On the other hand, increasing dietary protein level than $26 \%$ in Nile tilapia fingerlings did not improve body weight gain or feed conversion ratio that makes the rice of dietary crude protein not economic (ElDahhar, 1994). In the present study used primary productivity and artificial food for fish growth rearing in rice field water, because the quantity of natural food did not enough to faster fish growth, especially, the period of cultivation rice production under Egyptian condition is the shortest time (3 months). Therefore, the present study research aimed to study the effect of different protein diets \% or protein intake fed per fish rearing in rice field water on growth performance.

\section{MATERIALS AND METHODS}

The present studies were carried out in Sherbeen Center of Land cultured by rice yield, which it is far approximately $22 \mathrm{~km}$ from East Al-Mansoura City, Dakahlia Governorate. This study is design to investigate some factors affecting on natural food in water rice (water quality) field with or without using artificial feeds. Addition to its effects on growth performance of Nile tilapia (Oreochromis niloticus) fingerlings under Egyptian condition. The experimental design of these studies are presented in the following table using fourteen rectangle earthen ponds.

Table 1. The experimental design

\begin{tabular}{lccccc}
\hline & & \multicolumn{5}{c}{ Type of feed } \\
\cline { 3 - 6 } Treatment & $\begin{array}{c}\text { Pond } \\
\text { No. }\end{array}$ & $\begin{array}{c}\text { Natural } \\
\text { (Phyto \& }\end{array}$ & $\begin{array}{c}\text { Crude } \\
\text { protein } \\
\text { diet } \\
\text { No. }\end{array}$ & $\begin{array}{c}\text { Feeding } \\
\text { rate } \\
\text { zooplankton) }\end{array}$ & $\begin{array}{c}\text { Protein* intake } \\
\text { levels (PI) } \\
\text { g/100g fish } \\
\text { body weight }\end{array}$ \\
\hline T1 Control & $1 \& 2$ & + & - & - & - \\
T2 & $3 \& 4$ & + & 20 & 3.0 & 0.6 \\
T3 & $5 \& 6$ & + & 20 & 4.5 & 0.9 \\
T4 & $7 \& 8$ & + & 25 & 2.4 & 0.6 \\
T5 & $9 \& 10$ & + & 25 & 3.6 & 0.9 \\
T6 & $11 \& 1$ & + & 30 & 2.0 & 0.6 \\
T7 & 2 & & & & 0.9 \\
& $13 \& 1$ & + & 30 & 3.0 & \\
\hline
\end{tabular}

Where: $+=$ fish feeding of natural food (T1 as control fish).

$*$ Protein diet intake $=$ protein diet $\% \times$ feed intake $/ 100$

The experimental fishes were Nile tilapia (Oreochromis niloticus) fingerlings, because, it were considered as an efficient converter for both plankton (phyto \& zooplankton) and artificial diets to body growth or its wide variety of food consumption. There are three commercial diets used in the experimental study for feeding Nile tilapia fingerlings. These diets contained 20, 25 and 30\% crude protein (CP) and consisted of fish meal, soybean meal, rice bran, yellow corn, corn oil, molasses, vitamins and minerals mixtures with different ratio. Yet, chemical analyses 
of experimental diets (on dry matter basis) are shown in Table 2. Each group represented a dietary treatment in two replicates (ponds), except T1 (control) was fed only natural food. Each replicate consisted of 20 fingerlings stocked in a earthen pond sized $2 \mathrm{~m}^{3}$ (length $=2 \mathrm{~m}$, depth $=1 \mathrm{~m}$ ). The initial body weight of fingerlings was $47.36 \mathrm{~g}$. Each treatment was offered one of the tested diets at a rate of the biomass (Table 1). The diets were pelleted ( $2 \mathrm{~mm}$ diameter) form and fed for 7 days/week. The daily appointed-feed quantities were offered on three meals. The feeding experiment lasted approximately three months (started at $17^{\text {th }}$ July and finished at $15^{\text {th }}$ October) in year 2002.

Table 2. Chemical analysis of the experimental diets (on dry matter basis)

\begin{tabular}{lccc}
\hline \multirow{2}{*}{ Items \% } & \multicolumn{3}{c}{ Experimental diets } \\
\cline { 2 - 4 } & $\mathbf{2 0 \%}$ protein & $\mathbf{2 5 \%}$ protein & $\mathbf{3 0 \%}$ protein \\
\hline Dry matter & 91.00 & 91.00 & 91.00 \\
Crude protein & 19.99 & 24.98 & 29.97 \\
Ether extract & 9.29 & 10.38 & 10.90 \\
Carbohydrates & 64.75 & 58.42 & 52.61 \\
Ash & 5.97 & 6.22 & 6.52 \\
\hline
\end{tabular}

The following equations were used in calculating averages of weight gain (WG), relative growth rate (RGR), and condition factor $(\mathrm{K})$.

$\mathrm{WG}=\mathrm{W} 2-\mathrm{W} 1$ [Where: $\mathrm{W} 2=$ average final body weight $(\mathrm{g}) ; \mathrm{W} 1=$ Average initial body weight $(\mathrm{g})]$.

$\mathrm{RGR} \%=[(\mathrm{FW}-\mathrm{IW}) / \mathrm{IW}] \times 100$

Where: $\mathrm{FW}=$ final body weight $(\mathrm{g})$; IW = initial body weight $(\mathrm{g})$

$\mathrm{K}=(\mathrm{W} / \mathrm{L}) \times 100$ [Where: $\mathrm{W}=$ Body weight $\left.(\mathrm{g}) ; \mathrm{L}=(\text { Body length } \mathrm{cm})^{3}\right]$.

All numeral data obtained in the present study were statistically analyzed using statistical software (Statgraphics, Version 5.0, STSC, Rockville, 1991). The differences between treatments or within treatments were significant, F-test was calculated according to Duncan (1955) to comparison between effects of factors under studied.

\section{RESULTS AND DISCUSSION}

As shown from Table 3, grand means of body weights (regardless T1 control diet and feeding rate $\%$ ) were affected by different treatments (dietary protein $\%$, protein intake and their interactions) during the experimental periods (30 days each). Tilapia body weights were significantly $(\mathrm{P}<0.01)$ improved at the different intervals except at initial weight $(\mathrm{P} \geq 0.05)$ of the experiment. Also, comparison between the effect of natural food (T1) and artificial feed supplemented (T2 to T7) on grand means of live body weight during the experimental intervals are presented in Table 3. 
Table 3. Effect of different treatments on means of live body weights during the experimental periods of Nile tilapia (Oreochromis niloticus)

\begin{tabular}{|c|c|c|c|c|}
\hline Treatments & $\begin{array}{c}\text { W0 } \\
\text { (initial } \\
\text { weight) }\end{array}$ & $\begin{array}{c}\text { W1 } \\
\text { (at } 30 \text { days) }\end{array}$ & $\begin{array}{c}\text { W2 } \\
\text { (at } 60 \text { days) }\end{array}$ & $\begin{array}{c}\text { W3 } \\
\text { (at } 90 \text { days) }\end{array}$ \\
\hline \multicolumn{5}{|c|}{ Protein diet \% } \\
\hline $\begin{array}{l}\text { Control } \\
\text { ( } 0 \% \text { protein) }\end{array}$ & $47.96 \pm 1.4$ & $58.91 \pm 1.2^{\mathrm{C}}$ & $73.03 \pm 1.26^{\mathrm{D}}$ & $85.39 \pm 1.74^{\mathrm{D}}$ \\
\hline $20 \%$ protein & $47.20 \pm 0.94$ & $69.51 \pm 1.02^{\mathrm{B}}$ & $89.23 \pm 1.06^{\mathrm{C}}$ & $128.03 \pm 1.52^{\mathrm{C}}$ \\
\hline $25 \%$ protein & $47.11 \pm 1.03$ & $74.21 \pm 0.86^{\mathrm{A}}$ & $94.92 \pm 0.96^{\mathrm{B}}$ & $146.35 \pm 2.21^{\mathrm{B}}$ \\
\hline $30 \%$ protein & $47.09 \pm 1.01$ & $73.65 \pm 0.73^{\mathrm{A}}$ & $104.50 \pm 1.09^{\mathrm{A}}$ & $169.32 \pm 1.38^{\mathrm{A}}$ \\
\hline \multicolumn{5}{|c|}{ Protein intake level* } \\
\hline $20 \%(P . D)$ & $47.21 \pm 1.38$ & $67.24 \pm 1.45^{\mathrm{A}}$ & $87.36 \pm 1.35$ & $124.81 \pm 2.14^{\mathrm{A}}$ \\
\hline \multicolumn{5}{|l|}{0.6} \\
\hline 0.9 & $47.20 \pm 1.29$ & $71.79 \pm 1.35^{\mathrm{B}}$ & $91.11 \pm 1.59$ & $131.24 \pm 2.05^{\mathrm{B}}$ \\
\hline $25 \%$ (P.D) & $47.34 \pm 1.67$ & $72.86 \pm 1.29$ & $92.76 \pm 1.39^{\mathrm{A}}$ & $134.2 \pm 3.11^{\mathrm{A}}$ \\
\hline \multicolumn{5}{|l|}{0.6} \\
\hline 0.9 & $46.88 \pm 1.57$ & $75.56 \pm 1.12$ & $97.09 \pm 1.26^{\mathrm{B}}$ & $158.51 \pm 1.59^{\mathrm{B}}$ \\
\hline $30 \%$ (P.D) & $47.15 \pm 1.38$ & $71.97 \pm 0.98^{\mathrm{A}}$ & $102.23 \pm 1.41^{\mathrm{A}}$ & $164.36 \pm 1.54^{\mathrm{A}}$ \\
\hline \multicolumn{5}{|l|}{0.6} \\
\hline 0.9 & $47.03 \pm 1.49$ & $75.33 \pm 1.03^{\mathrm{B}}$ & $106.77 \pm 1.61^{\mathrm{B}}$ & $174.27 \pm 2.03^{\mathrm{B}}$ \\
\hline
\end{tabular}

* Protein intake $=$ protein diet $\% \times$ feed intake $/ 100$.

Means not followed by the same superscript letters in the row within the same period differ significantly at $(\mathrm{P} \leq 0.05$ and 0.01$)$.

The means of life body weight groups fed artificial feed (20, 25 and 30\% CP) improved (P $\leq 0.01)$ at 30 (W1), 60 (W2) and 90 (W3) days of the feeding experiment comparing with the control (Table 3 ). Meanwhile, comparison between the effect of protein intake on means of live body weights are presented in Table (3). Significant $(\mathrm{P} \leq 0.01)$ increases were found at the end of the following intervals (W1, W2 and $\mathrm{W} 3$ ) in all treatments (T2 to T7). Also, within protein intake (0.6) reflected lower $(\mathrm{P} \leq 0.01)$ body weight gain than $(0.9)$ at all the experiment intervals. The highest fish body weight was recorded by fish groups fed the high dietary protein level. The grand means were 128.03, 146.35 and $169 \mathrm{~g}$ fish for 20,25 and $30 \% \mathrm{CP}$, respectively, whereas protein intake were 141.12 and $154.67 \mathrm{~g}$ fish for 0.6 and 0.9 $\mathrm{g} / 100 \mathrm{~g}$ fish body weight, respectively.

Weight gains at 30, 60 and 90 days and total gain (0-90 days) were highly significantly $(\mathrm{P} \leq 0.01)$ affected by dietary protein levels (Table 4$)$; yet the tested diet contained $30 \%$ protein at the whole period (0-90 day) recorded higher total weight gain $(121.79 \mathrm{~g})$ than other three periods. Feeding levels (protein intake) affected positively $(\mathrm{P} \leq 0.01)$ weight gains at different experimental period except at the $2^{\text {nd }}$ period (60 days) and the whole period (90 days). The means of weight gain at high protein level were higher than the low level at all the experimental periods. 
Table 4. Effect of different treatments on grand means of body weight gains (G) during the experimental periods of Nile tilapia (Oreochromis niloticus)

\begin{tabular}{|c|c|c|c|c|}
\hline Treatments & G 1 & G 2 & G 3 & T.G. \\
\hline \multicolumn{5}{|c|}{ Protein diet $\%$} \\
\hline Control (0\%P.D) & $10.96 \pm 0.58^{\mathrm{D}}$ & $14.12 \pm 0.39^{\mathrm{D}}$ & $12.36 \pm 0.76^{\mathrm{D}}$ & $37.43 \pm 0.87^{\mathrm{D}}$ \\
\hline $20 \%$ protein diet & $22.31 \pm 0.51^{\mathrm{C}}$ & $19.72 \pm 0.4^{\mathrm{C}}$ & $38.79 \pm 0.75^{\mathrm{C}}$ & $80.82 \pm 0.78^{\mathrm{C}}$ \\
\hline $25 \%$ protein diet & $27.10 \pm 0.51^{\mathrm{A}}$ & $20.72 \pm 0.32^{\mathrm{B}}$ & $51.43 \pm 0.43^{\mathrm{B}}$ & $98.93 \pm 0.60^{\mathrm{B}}$ \\
\hline $30 \%$ protein diet & $26.55 \pm 0.51^{\mathrm{B}}$ & $30.85 \pm 0.44^{\mathrm{A}}$ & $64.82 \pm 0.59^{\mathrm{A}}$ & $121.79 \pm 0.74^{\mathrm{A}}$ \\
\hline \multicolumn{5}{|c|}{$\begin{array}{l}\text { Protein intake levels* } \\
\end{array}$} \\
\hline \multirow[t]{2}{*}{$20 \%$ (P.D) } & $20.03 \pm 0.75^{\mathrm{B}}$ & $20.12 \pm 0.6$ & $37.45 \pm 1.1$ & $77.6 \pm 1.0^{\mathrm{B}}$ \\
\hline & $24.59 \pm 0.48^{\mathrm{A}}$ & $19.32 \pm 0.53$ & $40.14 \pm 0.98$ & $84.05 \pm 0.98^{\mathrm{A}}$ \\
\hline \multirow[t]{2}{*}{$25 \%(P . D)$} & $25.52 \pm 0.64^{\mathrm{B}}$ & $19.91 \pm 0.34^{\mathrm{B}}$ & $41.44 \pm 2.06^{\mathrm{B}}$ & $86.86 \pm 2.01^{\mathrm{B}}$ \\
\hline & $28.68 \pm 0.72^{\mathrm{A}}$ & $21.53 \pm 0.52^{\mathrm{A}}$ & $61.42 \pm 0.61^{\mathrm{A}}$ & $111.63 \pm 0.62^{\mathrm{A}}$ \\
\hline \multirow[t]{2}{*}{$30 \%$ (P.D) } & $24.82 \pm 0.62^{\mathrm{B}}$ & $30.26 \pm 0.53$ & $62.13 \pm 0.55^{\mathrm{B}}$ & $117.21 \pm 0.44^{\mathrm{B}}$ \\
\hline & $28.29 \pm 0.72^{\mathrm{A}}$ & $31.44 \pm 0.69$ & $67.51 \pm 0.85^{\mathrm{A}}$ & $127.24 \pm 0.88^{\mathrm{A}}$ \\
\hline
\end{tabular}

*- Protein in take $=$ protein diet $\% \times$ feed intake $/ 100$.

Means not followed by the seam letter in the row (within the same period) differ significantly at $(\mathrm{P} \leq 0.05$ and 0.01 ,respectively).

From the results presented in Table 4 , there were significant $(\mathrm{P} \leq 0.01)$ differences among control diet and tested diets during the all experiment periods and from zero to the end of the experiment concerning body weight gains. Body weight gains, which were calculated at periods of the experiment, reflected significantly $(\mathrm{P} \leq 0.01)$ higher values for tested diets than control diet. Table 4 showed weight gains were increased with increasing protein diets $\%$ or levels of protein intake. The third tested diet containing $30 \%$ crude protein had the best significant $(\mathrm{P}<0.01)$ values of body weight gains (means or totally) compared with the other diets during the experimental periods of Nile tilapia.

Grand means of both relative growth rates (RGR\%) were positively and significantly $(\mathrm{P} \leq 0.01)$ affected by dietary protein diets at the levels $(20,25$ and $30 \%$ $\mathrm{CP}$ ) during the periods of $0-30,30-60,60-90$ and $0-90$ days of the feeding experiment. It were not gradually increased for RGR $\%$ as presented in Table 5 . The effects of protein diet $\%$ and protein intake levels increased $(\mathrm{P} \geq 0.05)$ at 30-60 days and $(\mathrm{P} \leq 0.01)$ only at $60-90$ days in relative growth rates.

Moreover, RGR\% reflected significantly $(\mathrm{P} \leq 0.01)$ for the all periods estimated, higher values for tilapia fishes in treatments (dietary protein supplemented with natural food) than the control diet and the $3^{\text {rd }}$ tested diet $(30 \% \mathrm{CP})$ compared with the $1^{\text {st }}$ and $2^{\text {nd }}$ tested diets during the whole experimental period (0-90 days). The $3^{\text {rd }}$ tested diet had the best values of RGR\% (268.92) compared with the other diets which showed different values ranged from $78.91 \& 0.279$ (control diet) to $220.73 \&$ $0.552(25 \% \mathrm{CP})$ during the whole period (0-90 days), Table 5. showed the effects of protein diet $\%$ were significantly $(\mathrm{P} \geq 0.01)$ for $\mathrm{RGR} \%$ means at different experimental period. Meanwhile, the level of 0.9 protein intake showed better RGR $\%$ than by 0.6 protein intake during the experimental periods, Table 5 . 
Table 5. Effect of different treatments on grand means of relative growth rate (R.G.R.\%) during the experimental periods of Nile tilapia (Oreochromis niloticus)

\begin{tabular}{|c|c|c|c|c|}
\hline Treatments & R.G.R 1 & R.G.R & R.G.R 3 & T.R.G.R \\
\hline \multicolumn{5}{|c|}{ Protein diet \% } \\
\hline Control (0\%P.D) & $24.24 \pm 2.55^{\mathrm{C}}$ & $23.49 \pm 1.14^{\mathrm{C}}$ & $16.89 \pm 1.44^{\mathrm{D}}$ & $78.91 \pm 3.59^{\mathrm{D}}$ \\
\hline $20 \%$ P.D & $49.12 \pm 1.68^{\mathrm{B}}$ & $29.01 \pm 0.83^{\mathrm{B}}$ & $43.71 \pm 0.88^{\mathrm{C}}$ & $175.89 \pm 3.45^{\mathrm{C}}$ \\
\hline $25 \%$ P.D & $62.27 \pm 2.68^{\mathrm{A}}$ & $28.19 \pm 0.55^{\mathrm{B}}$ & $53.91 \pm 1.5^{\mathrm{B}}$ & $220.73 \pm 6.8^{\mathrm{B}}$ \\
\hline $30 \%$ P.D & $59.96 \pm 2.26^{\mathrm{A}}$ & $41.88 \pm 0.42^{\mathrm{A}}$ & $62.95 \pm 0.74^{\mathrm{A}}$ & $268.92 \pm 5.81^{\mathrm{A}}$ \\
\hline \multicolumn{5}{|c|}{ Protein intake levels* } \\
\hline \multirow[t]{2}{*}{$20 \%$ P.D } & $44.46 \pm 2.57^{\mathrm{B}}$ & $30.83 \pm 1.38^{\mathrm{A}}$ & $42.93 \pm 1.14$ & $169.24 \pm 4.78$ \\
\hline & $53.78 \pm 1.91^{\mathrm{A}}$ & $27.2 \pm 0.85^{\mathrm{B}}$ & $44.5 \pm 1.34$ & $182.54 \pm 4.81$ \\
\hline \multirow[t]{2}{*}{$25 \%$ P.D } & $58.58 \pm 3.63$ & $27.64 \pm 0.66$ & $44.23 \pm 1.86^{\mathrm{B}}$ & $190.95 \pm 6.57^{\mathrm{B}}$ \\
\hline & $65.96 \pm 3.89$ & $28.74 \pm 0.87$ & $63.6 \pm 0.90^{\mathrm{A}}$ & $250.52 \pm 9.92^{\mathrm{A}}$ \\
\hline \multirow[t]{2}{*}{$30 \%$ P.D } & $55.99 \pm 3.13$ & $42.08 \pm 0.52$ & $61.22 \pm 0.99$ & $257.85 \pm 8.31$ \\
\hline & $63.92 \pm 3.17$ & $41.68 \pm 0.66$ & $63.67 \pm 1.08$ & $280.0 \pm 7.83$ \\
\hline
\end{tabular}

$*$ Protein intake $=$ protein diet $\% \times$ feed intake $/ 100$.

Means not followed by the same letters in the same row (within the same period) are significantly differ at $\mathrm{P} \leq 0.05$ and 0.01 , respectively.

R.G.R. $1=$ Relative growth rate from 0-30 days.

R.G.R. 2 = Relative growth rate from 30-60 days.

R.G.R. $3=$ Relative growth rate from 60-90 days.

T.R.G.R. $=$ Total relative growth rate during the whole experimental period ( $0-90$ days).

The highest means and overall means $(\mathrm{P} \leq 0.01)$ of condition factor $(\mathrm{KF})$ was found in the third treatment (diet contained on $30 \% \mathrm{CP}$ ) at the end of the last $3^{\text {rd }}$ interval (60-90 days) and $4^{\text {th }}$ interval (0-90 days), respectively, when it were compared with those recorded herein of the other treatment and intervals. The general trend of $\mathrm{KF}$ values were the increase from the $1^{\text {st }}$ to $3^{\text {rd }}$ intervals (periods) for artificial diets contained on 20 or $30 \% \mathrm{CP}$. Yet, it were increase at the end of the $1^{\text {st }}$, $2^{\text {nd }}$ periods and trended to decrease at the end of the $3^{\text {rd }}$ period using diet $25 \% \mathrm{CP}$. Moreover, the effects of the two protein intake levels were significant $(\mathrm{P} \leq 0.05)$ or highly significant $(\mathrm{P} \leq 0.01)$ for $\mathrm{KF}$ at the $3^{\text {rd }}$ and $4^{\text {th }}$ periods, respectively (Table 6). The comparison between influenced control and tested diets in KF at different periods are found in Table 6 . Similar effects has been shown by all experimental diets in increased KF and highly significant at $(\mathrm{P} \leq 0.01)$ for all the end of periods studied. Yet, it improved values at the $4^{\text {th }}$ period, which were equals $1.98,1.90,2.19$ and 2.69 when used diets contained $0.0,20,25$ and $30 \% \mathrm{CP}$. 
Table 6: Effect of different treatments on means of the condition factor (K.F) during the experimental periods of Nile tilapia (Oreochromis niloticus)

\begin{tabular}{|c|c|c|c|c|c|}
\hline \multicolumn{2}{|l|}{ Treatments } & K. $\mathbf{F}_{0}$ & K. $\mathbf{F}_{1}$ & K. $\mathbf{F}_{2}$ & K. $\mathbf{F}_{3}$ \\
\hline \multicolumn{2}{|l|}{$\begin{array}{l}\text { Control } \\
\text { (0\% Protein) }\end{array}$} & $1.6745 \pm 0.0042^{\mathrm{B}}$ & $1.8548 \pm 0.0073^{\mathrm{B}}$ & $1.9431 \pm 0.0082^{\mathrm{B}}$ & $1.9849 \pm 0.0076^{\mathrm{C}}$ \\
\hline \multicolumn{2}{|l|}{$20 \%$ protein } & $1.5219 \pm 0.0028^{\mathrm{C}}$ & $1.5941 \pm 0.0027^{\mathrm{D}}$ & $1.6691 \pm 0.0028^{\mathrm{C}}$ & $1.9020 \pm 0.0028^{\mathrm{D}}$ \\
\hline \multicolumn{2}{|l|}{$25 \%$ protein } & $1.7445 \pm 0.0038^{\mathrm{A}}$ & $1.7074 \pm 0.0029^{\mathrm{C}}$ & $1.5888 \pm 0.0012^{\mathrm{D}}$ & $2.1915 \pm 0.0024^{\mathrm{B}}$ \\
\hline \multicolumn{2}{|l|}{$30 \%$ protein } & $1.6759 \pm 0.0037^{\mathrm{B}}$ & $2.1705 \pm 0.0069^{\mathrm{A}}$ & $2.2212 \pm 0.0071^{\mathrm{A}}$ & $2.6983 \pm 0.0044^{\mathrm{A}}$ \\
\hline \multicolumn{6}{|c|}{ Protein intake level * } \\
\hline \multirow[t]{2}{*}{$20 \%$ protein } & 0. & 1.508 & $1.6895 \pm 0.0047^{\mathrm{A}}$ & $1.8209 \pm 0.0039^{\mathrm{A}}$ & $1.9511 \pm 0.0031^{\mathrm{A}}$ \\
\hline & 0.9 & $1.5343 \pm 0.0$ & $1.4987 \pm 0.0015^{\mathrm{B}}$ & $1.5172 \pm 0.0018^{\mathrm{B}}$ & $1.8529 \pm 0.0011^{\mathrm{B}}$ \\
\hline \multirow[t]{2}{*}{$25 \%$ protein } & 0.6 & $1.8220 \pm 0.0053^{\mathrm{A}}$ & $1.7942 \pm 0.0054^{\mathrm{A}}$ & $1.6014 \pm 0.0023$ & $2.0503 \pm 0.0032^{\mathrm{B}}$ \\
\hline & 0.9 & $1.6670 \pm 0.0051^{\mathrm{B}}$ & $1.6205 \pm 0.0016^{\mathrm{B}}$ & $1.5763 \pm 0.0007$ & $2.3307 \pm 0.0018^{\mathrm{A}}$ \\
\hline \multirow[t]{2}{*}{$30 \%$ proein } & 0.6 & & 2.114 & 2.24 & $2.6425 \pm 0.0064$ \\
\hline & 0.9 & $1.6887 \pm 0.0032$ & $2.2270 \pm 0.0076$ & $2.1997 \pm 0.0079$ & $2.7541 \pm 0.0059$ \\
\hline
\end{tabular}

*: Protein intake $=$ Protein diet $\% \times$ feed intake $/ 100$.

The means not followed by the same letters in the row differ significantly at $(\mathrm{P} \leq 0.05$ and 0.01 , respectively).

$\mathrm{K} . \mathrm{F}_{\cdot 0}=$ The condition factor at initial of the experiment.

K. $\mathrm{F}_{\cdot 1}=$ The condition factor at 30 days.

$\mathrm{K} . \mathrm{F}_{\cdot 2}=$ The condition factor at 60 days.

K. $\mathrm{F}_{\cdot 3}=$ The condition factor at 90 days.

Means of KF values and analysis of variance affected by different protein intake of Nile Tilapia at different periods are presented in Table 6. The highest level of dietary protein intake improved $(\mathrm{P} \leq 0.01) \mathrm{KF}$ values of Tilapia at the most studied periods, particularly at the hole period (0-90 days) except, the effect of the diet $(30 \%$ $\mathrm{CP}$ ), which was not significant. Results obtained from these traits are recorded in Table 6 showed the effects of both dietary protein percentages and protein intake and their interactions, on the values of body measurements [(weight and length), body weight gains], growth rates (RGR\%) and condition factor (KF) depended on natural and artificial foods for Nile tilapia (Oreochromis niloticus) fingerling reared in water rice field at different experimental periods. These values such as, grand means (as main factors) as well as, means [as treatment effects (T2-T7) or interactions between main factors] of these traits previously mentioned were positively affected by increasing both of dietary protein $\%$ or protein intake at it were together effects on most criteria estimated in the present study. Therefore, the highest values of the previous traits were estimated in treatment 7 (30\% CP with high level of protein intake) as compared with the other diets [tested diets (2-6) and natural feed (T1 or $0 \%$ protein)] for all experimental periods.

Results obtained herein, agreement with those reported by El-Shebly (2000) and Khalil, et al. (2001). They reported that protein is the basic building nutrients of any growing animals and muscle constitutes, anatomically, the major component of fish body, protein usually account for $68-85 \%$ of the dry matter of fish carcasses. Also, dietary protein is always considered to be of primary importance in fish feed, as the protein requirements of fish are higher than those of terrestrial animals and protein sources account for more half of total feed cost (El-Ebiary, 1994).

The superiority of treatment no 7. in fish growth performance may be due to the feeding regime used, since aquaculture practices need to be intensified to varying 
degrees, mostly through increasing levels of supplemental feeding (DeSilva and Davy, 1992). However, the nutrients are required for building the muscles in rapidly growing fish, since the faster the growth the greater the amount of feed is converted to fish (Asgard and Hillestad, 1998). Therefore, Middendorp and Huisman (1995) reported significantly better growth rates on progressive feeding strategy.

In the case of fry and fingerlings reared indoor aquaria (Omar, 1994). Similar results were obtained by Omar, et al., (1997) who showed that 30\% CP diet produced the best growth performance of $O$. niloticus fingerlings. Meanwhile, Magouz (1990) found that the dietary protein level of $O$. niloticus could be reduced from $40 \%$ to $33 \%$ without any significant effect on growth of fish. The dietary crude protein levels effect was more pronounced in the smaller fish referring to the higher protein requirements of the smaller fish than the older ones (Abdelhamid, et al., 1998). Moreover, increasing dietary crude protein from 25 to $30 \%$ led to increasing body weight of Nile tilapia fishes, as with as, body gains (as length and weight), RGR, SGR\%, (Abdelhamid, et al., 1997).

On the other hand, increasing dietary protein level than $25 \%$ in Nile tilapia fingerlings did not improved body weight gains or feed conversion ratio, that makes the rise of dietary crude protein is not economic (El-Dahhar, 1994). Whereas, it was significant on feed intake and daily gain (Khalil, et al., 2001 and Mostafa, 2001). Thus, Dureza and Belmonte (1995) found that feeding rate (4-10\%) did not significantly influence the mean body weight per fish.

Tilapia production under any culture system are affected by many factors mainly feeding habits, natural or artificial feeds, dietary protein levels, feeding level which are effected directly by protein intake per fish, feeding frequency, etc. Tilapia required the same nutrients (protein, lipids, carbohydrates, vitamins and minerals) for maintenance and production. Generally, tilapia obtains their nutrients from natural food and/or from artificial feed.

\section{REFERENCES}

Abdelhamid, A.M., 2000. Scientific Fundamentals of Fish Production and Husbandry. An Arabic Textbook, $2^{\text {nd }}$ ed., Published by the author himself.

Abdelhamid, A.M., F.F. Khalil, M.E. Elbarbary, 1997. Effect of different dietary crude protein levels supplemented with graded levels of Flavomycin on growth performance of Nile tilapia fry and their utilization of different nutrients. Egypt. J. Aquat. Biol. and Fish, 1 (3): 43-108.

Abdelhamid, A. M., F.F. Khalil and M.E. El-Barbary, 1998. Effect of using graded levels of gibberellic acid in diets differing in the crude protein levels on performance and chemical composition of Nile tilapia fingerlings. Egypt. J. Aquat. Biol and Fish, 2 (4): 221-232.

Asgard, T. and M. Hillestad, 1998. Eco-Friendly aquafeeds need accurate design. Feed Tech., 2(6): 13-15.

Bardach, J.E., J.H. Ryther and W.O. Mclarney, 1972. Aquaculture, the forming and husbandry of freshwater and marine organisms. Johnwiley \& Sons, Inc., New York, USA. 
Bolarin, J.D. and R.D. Haller, 1982. The intensive culture of tilapia in tanks, raceways and cages. In: Recent Advances in Aquaculture, Westview Press, Boulder, Colorado, pp: 265-356.

DeSliva, S. S. and F. B. Davy, 1992. Fish nutrition research for semi-intensive culture system in Asia. Asian Fish, Sci., 5: 12-144.

Duncan, D., 1955. Multiple range and multiple F-test. Biometrics, 11: 1-42.

Dureza, I.A. and B.D. Belmonte, 1995. Effect of feeding schemes and feeding frequencies on growth and survival of tilapia hybrid (Oreochromis niloticus $\times O$. mossambicus) raised in cages in brackish-water. Univ. Philippines Res. Digest., 3 : 258-259.

Eid, A.M.S., 1993. Fish Nutrition. (an Arabic Textbook), Fac. Agric., Sues Canal Univ., Ismaillia, Egypt.

El-Dahhar, A.A. 1994. Protein requirements of fry and fingerlings o Nile tilapia (Oreochromis niloticus) fed varying protein level in Egypt. J. Agric. Sci., Mansoura Univ., 19: 117-128.

El-Ebiary, E.H.A. 1994. Studies on fish production: Relationship between nutrition and reproduction of Tilapia sp. Ph. D. Thesis, Fac. Agric. Alex. Univ.

El-Shebly, A.A.A., 2000. Fish production under semi-intensive system. M. Sc. Thesis, Fac. Agric. Mansoura Univ.

Jauncey, K. and B. Ross, 1982. A Guide to Tilapia Feeds and Feeding. Inst. Aquaculture, Univ. Strlin, Scotland, pp:111.

Khalil, F.F., A.M. Abdelhamid and M.E.A. Mostafa, 2001. Nutitional influences on Nile tilapia broodstock fish (Oreochromis niloticus): 1- Growth performance and feed utilization. Egyptian J. Nutrition and Feed, 4: 685-693.

Loares, B. T. R. R., R. P. Ribriro, L. Vargas, H. L. N. Moreira' F. Sussel, I. A. Povh, and F. Cavichiolo, 2001. Feeding management of fingerlings of Nile tilapia Oreochromis niloticus (L.) associated with physical, biological and chemical variables of the environment. Acta Scientiarum, 23(4): 877-883.

Magouz, F.I., 1990. Studies on optimal protein and energy supply for tilapia (Oreochromis niloticus) in intensive culture. Ph. D. Thesis, Fac. Agric., GeorgAugust. Univ., Göttingen.

Middendorp, A.J. and E.A. Huisman, 1955. Pond farming of Nile tilapia, Oreochromis niloticus $(L)$, in northern Cameroon. Comparing two different strategies for feeding cottonseed cake in tilapia male monosex culture. Aquacult. Res., 28: 731-738.

Mostafa, M.E.A., 2001. Nutritional influences on reproductive performance of fish. M. Sc. Thesis, Fac. Agric., Mansoura Univ.

Omar, E.A., 1994. Supplementary feeding of tilapia (Oreochromis niloticus) cultured in earthen ponds. 1-Effect of dietary protein levels and sources. Alex. J. Agric. Res., 39: 109-118.

Omar, E. A., Al-Sagheer, A.M. Nour and A.R. Akkada, 1997. Effect of protein level and stocking density on growth performance, feed utilization and resistance of Nile tilapia (Oreochromis niloticus) to infection against aeromonos Septicemia (Aeromonas hydrophila). Proc. Workshop CIHEAM on TECAM, Jointhy by CIHEAM \&FAO.

Rockville, 1991. Statgraphics Program, version 5.0 STSC.

Sivalingam S., 1975. The biological of cultivable brackish water and marine fishes in Africa. FAO/CIFA Symp., Aquaculture, Africa. Chana, FAO/CIFA. 15/SE.280. 
إستزراع البلطي النيلي في مياه حقول الأرز ا-تأثير إضافة العلائق الصناعية علي أداء النمو فتحي فتوح محمد خليل' و مدحت السعيد عبد الفتاح سيدين

1 - قسم إنتاج الحيوان، كلية النزاعة، جامعة المنصورة، ب-المعدل المركني للبحوث النزاعية، العباسة، أبو حماد، شرقية

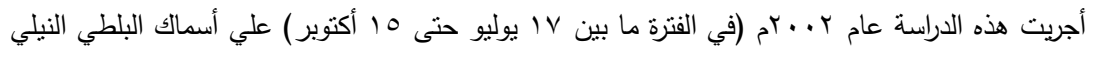

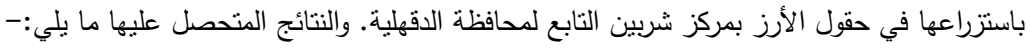

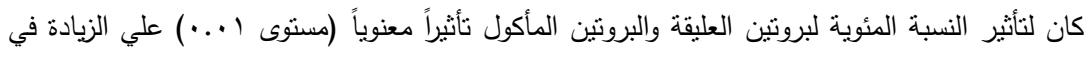
وزن الجسم خلال الفترات التجريبية المختلفة.

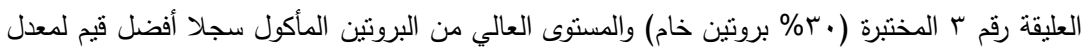

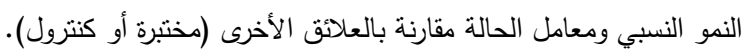

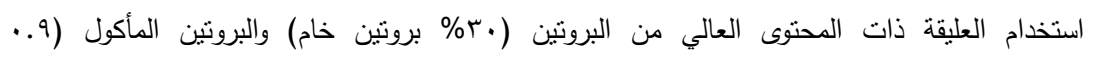

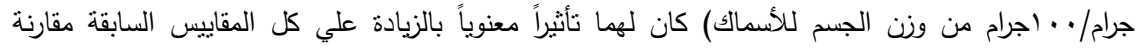
بالمستويات المنخفضة لهما.

وهذه الدراسة تثير إلي أن كمية الغذاء الطبيعي غير كافية لإنسراع النمو في أسماك البلطي النيلي، لذا

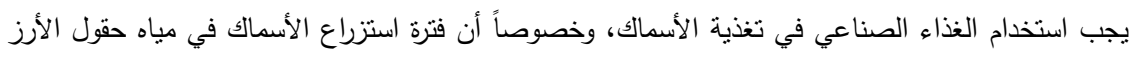
قصبرة جداً (r شهور). 